\title{
Follow-Up Study
}

National Cancer Institute

\section{Source}

National Cancer Institute. Follow-Up Study. NCI Thesaurus. Code C15234.

Study in which persons exposed to risk or given a designated preventive or therapeutic regimen are observed over a period or at intervals to determine the outcome of the exposure or regimen. 